Јован Пејчић

УДК 821.163.41.09 Црњански М. ДОИ https://doi.org/10.18485/ai_lik.2016.2.3.1

\title{
ПРАВИ ПЕСНИК НЕ МОЖЕ УМРЕТИ ПРЕ НЕГО ШТО ИСПУНИ СВОЈЕ ЈА, СВОЈУ СУДБИНУ
}

\author{
Разговор са Милошем Црњанским
}

УВОД У РАЗГОВОР

Разговор који читаоци имају пред собом водио сам са Милошем Црњанским 25. октобра 1973. године, два дана пре његовог 80. рођендана. С молбом за интервју обратио сам се

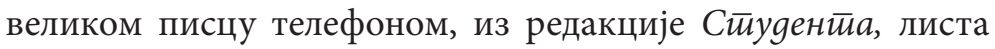
студената Београдског универзитета (у којем сам тада био уреднички сарадник на страницама за културу и књижевност), око пола три поподне.

Милош Црњански одмах је пристао на разговор. Да се један студентски лист интересује за њега, то му - казао је без сувишнога женирања - „чини част“. Он је за то, наставио је, да разговор водимо у његовом стану пошто му здравље није најбоље. Како управо тече Сајам књига, па га позивају сви и на све стране, што га замара, предложио је да се сретнемо „колико данас“, на пример у четири, и да, уз поподневни чај, „урадимо посао“.

Признајем, ухватила ме блага паника од толиких и таквих предлога.

Питао ме још да ли ћу његове одговоре бележити, или ћу имати магнетофон, па да он бележи.

Одговорио сам да ћу урадити како он жели.

Црњански је казао да је, због његовог времена, којег има мало, боље да разговор „буде у магнетофон“.

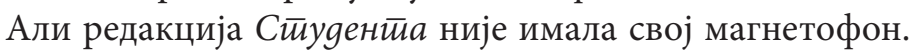
Он то није могао знати. Црњанскоме то нисам ни признао - било ме, тада, не знам ни данас због чега, просто срамота.

У журби да стигнем у довогорено време (било ми је остало још сат и по̂), сетио сам се Драгиње Урошевић, 
песникиње, која је тих месеци радила на радију, у „Београду 202“. Замолио сам ја да, како зна, обезбеди магнетофон за разговор с Црњанским.

Драгиња и ја смо, тако, у 16 сати по подне били код Црњанског: Улица маршала Толбухина 81, спрат II, десно од степеништа, стан 8 - тачно изнад ресторана „Влатава“.

Мој интервју са Црњанским трајао је непуна три сата. ${ }^{1}$

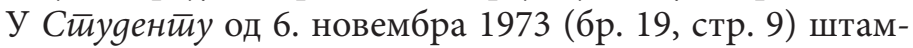
пан је мој разговор са Црњанским, али не у целости, и не у оном облику у којем је Црњански желео: главни уредник био је предвидео „једну страницу за разговор са Милошем Црњанским - и то је то“.

Тако, догодило се да неки делови ауторизованога интервјуа буду изостављени. И да - тако ћу се изразити - реченице-пасуси Црњанског буду уланчавани (с пристанком самога Црњанског) на један крајње нецрњансковски начин, у дуге целине које, због тога, на многим местима делују као да рука Црњанског на њима није радила.

Уза све друго, сам писац је (не знам да ли у горчини, јер ништа ми, у том смислу, није ни наговестио, камоли рекао), немилице „растерећивао“ - да тако кажем - вековечну своју „стратегију“ интерпункцијскога одређивања значења речи, и читавих делова реченица, па и пасуса.

Памтим само да је, при овој другој „ауторизацији“, казао отприлике: да реченица - кад већ није у могућности да „сама себи одређује смисао“ (што је, код њега, иначе, увек било) - мора бити сложена онако како је, на папиру, компонован цео текст.

Сада знам да је то била алузија на све оно што га је, од једнога студентскога листа, неочекивано са те стране, снашло.

То ме, с друге стране, сећа на један други разговор, који је Црњански године 1975. водио са студентима Филолошког факултета у Београду. Тада је, у одговору на питање једног

1 При ауторизацији, Црњански је доста текста пребрисао, све оно што је - ово су његове речи - „негде већ рекао“. Узгред, траке на које је разговор снимљен остале су код г. Светозара Влајковића, књижевника, уредника културе „Индекс 202“. Узалудно сам, доцније, покушавао да до њих дођем, или да ми се пресниме. Не знам ни да ли су сачуване. 
песника-почетника, казао како је човек дужан, кад нешто почне, да иде до краја. Или има да одустане од свега, и да сматра, и да тако живи, као да ништа, никад, и није започињао.

Разговор који читоаци имају пред собом тачно је, дакле, онакав каквим га је Милош Црњански, у првобитној верзији (коју ја сматрам једино правом), оставио.

Ово објављивање, међутим, није прво.

При једном сусрету средином 1977. године у редакцији Трећег програма Радио Београда ја сам Касиму Прохићу, тада главном уреднику сарајевског Израза, изнео сву судбину мога разговора са Црњанским и он ме је позвао да изворну верзију текста објавим у његовом часопису,

Милош Црњански је, као што се зна, умро 30. новембра 1977. године.

У то време ја сам био на одслужењу редовнога војног рока у Вршцу. Јавио сам се из војске проф. Прохићу рекавши му да је тужан час Црњансковога одласка из живота прилика да му се одужимо и захвалимо аутентичним обликом Разі̄oвора, на којем смо он и ја, у октобру и почетком новембра 1973, по скидању с траке, радили готово две недеље.

Тако је било. С кратким мојим уводним записом, разговор се појавио у априлском броју Израза. ${ }^{2}$

Прича о моме интервјуу са творцем „мита“ о случају-комедијанту тиме се, на жалост, не завршава.

У значајној библиотеци „Разговори с писцима“ Београдског издавачко-графичког завода (БИГЗ) појавила се 1992. године књига разговора са Црњанским под насловм Исйунио сам своју суgбину. Приређивач њезин Зоран Аврамовић унео је у књигу и разговор који сам ја водио са Црњанским. Не, међутим, изворну верзију разговора, ону штампану у Изразу,

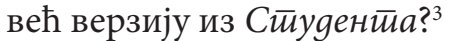

Непријатност о којој сам, одмах по изласку књиге, разговарао са г. Аврамовићем, поновила се још једанпут,

2 Вид. „Живот пролази као што пролази пролеће, као што пролазе птице. Сасвим лепо“. Разговор Јована Пејчића са Милошем Црњанским, Израз (Сарајево), XXXII/4 (1978), 409-419.

3 Уп. „Живот пролази као што пролази пролеће, као што пролазе птице“. Разговарао Јован Пејчић, у: Милош Црњански, Исйунио сам своју суgбину (прир. 3. Аврамовић), Београд 1992, 249-257. 
читавих седам година касније, у једанаестом тому Дела Милоша Црњанскоі, који је - како у књизи пише - „приредио, са сарадницима, Ж[иворад] Стојковић“. И овде је пре-

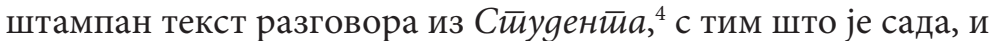
то је разлика у односу на зборник Исӣунио сам своју суgбину, пренето и слово којим читаоца уводим у свечаност обележавања Црњанскове осамдесетогодишњице. ${ }^{5}$ То су, дакле, разлози са којих приступам поновном објављивању разговра са Црњанским у његовом аутентичном облику. Само је овај текст истинит, и само иза њега можемо стајати мој велики саговорник и ја.

4 Уп. „Живот пролази као што пролази пролеће, као што пролазе птице“ (разговор J. Пејчића), у: Милош Црњански, Есеји и чланиц II (прир. Ж. Стојковић са сарадницима), Дела Милоша Црњанског, т. 11. књ. 22 и 23, Београд 1999, 580-586.

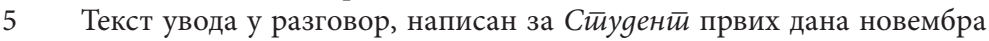
1973, гласи:

Двадесет седмог октобра прославио је Милош Црњански осамдесети свој рођендан.

Како на најдостојнији начин обележити овај свечани тренутак целокупне српске књижевности?

У последњих неколико година појавиле су се обимне књиге студија о стваралаштву великог писца.

Свакодневно на страницама књижевних листова и часописа освањују нови текстови посвећени Црњансковом делу.

Организују се разговори, преуспитују, критикују раније донесени и доносе нови судови.

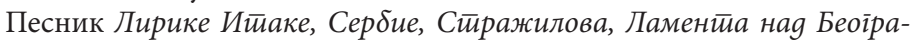
gом посматра све то са стране и - наставља да ради.

Писац Дневника о Чарнојевићу, Сеоба, Друіе кюиіе Сеоба, Коg Хийерборејац, Романа о Лондону снатри на великом пројекту о Микеланђелу. Аутор поетичне Маске и драма Конак и Тесла, тумач Шекспирових сонета и фантазмагоричних Дирерових визија, преводилац кинеске и јапанске лирике - исписује предано странице својих мемоара... Писац чија дела стоје у самом темељу модерне српске књижевности још једанпут потврђује правило да горостаси, да неимари људске културе целога свог живота - стварају. 


\section{РАЗГОВОР}

\section{ЖИВОТ ПРОЛАЗИ КАО ШТО ПРОЛЕЋЕ ПРОЛАЗИ, КАО ШТО ПТИЦЕ ПРОЛАЗЕ. САСВИМ ЛЕПО}

1. АКО СЕ РАЗВИЈА, ПЕСНИК ЈЕ УВЕК ЗАНИМЉИВ, ЧАК И У СТАРОСТИ. АКО ЈЕ, РАЗУМЕ СЕ, ПРАВИ ПЕСНИК, И АКО НЕ СТАНЕ

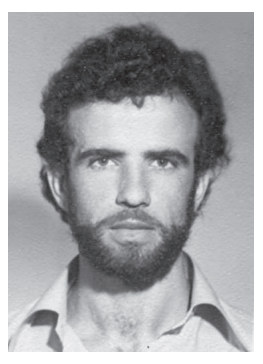

Јован Пејчић: Oсамgесей іолина живойа и, ако се сетиимо gа стие йрву иесму објавили 1908, близу сеgамgесети іодина сииваралачкоі раgа, нейобитиан су доказ о Вашем дубоком и животином и сииваралачком искустиву. Каgа се

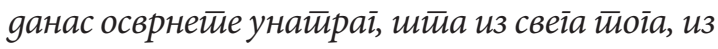
целине Вашеїа животиа и дела, издвајатете као йосебно важно?

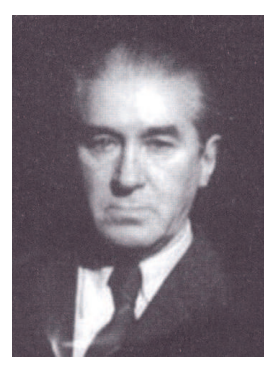

Милош Црњански: Први и основни утисак је то, да је случај хтео да дочекам осамдесет година и да, на тај начин, заокружим пут којим сам, у књижевности, ишао. То, да сам у 1908. писао, то значи да је једна песма штампана у Голубу, ђачком једном листу, а да многе друге, које и сада чувам, нису штампане. Оставићу их да виде људи, и да се смеју како ја пишем о Гундулићу, и како Гундулић, на позорници, говори, јер је то интересантно.

Друго, што кажете седамдесет и осамдесет година, па то је пут, којим песник, у своме развоју, корача. Ако је прави песник, разуме се, и ако не стане. То зависи од његове среhе, литерарне, у животу. Ако се развија, он је увек занимљив, чак и у старости. 
То су сви велики песници, у иностранству. Они пишу и до своје седамдесете, и осамдесете.

Код нас, међутим, дешава се да песници ућуте, рано. А ућути онај, ко доживи неку катастрофу, душевну, или у животу уопште.

Имамо и ми, додуше, песнике који су, до краја, писали. Ето, на пример, Змај Јован Јовановић. Он је целог живота писао. Али они, који су неку трагедију преживели, у животу, већина њих, они су стали. Због тога, или пак зато, што више нису могли да подносе оно, што се о њима пише.

Ја сам, све то, поднео, и писао сам и даље, јер сам схватио да је то мој позив.

\section{2. СВАКИ ПОЕТ ИМА, У СВОМ СТВАРАЮУ, ПОЈЕДИНЕ ЧИНОВЕ, КАО У ТЕАТРУ, У ДРАМИ}

Широк је лук Ваше йоезије, оg Лирике Итаке gо Ламента

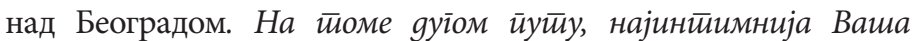
сирремљена, најунуйарнији Ваши ииворачки немири стиављали су йреg иесника Црьанскоі сииално нове изазове, који су, наравно, захиеевали нове и яруїојачије оgїоворе.

Тако је. Јер, сваки поет има, у свом стварању, поједине чинове, као у театру, у драми. У младости је била Лирика Ий $а$ $\kappa е$, зато што је то било такво доба, револуционарно. После имате „Сербиу“ која је огорчена поема љубави према своме народу.

Па сам отишао у иностранство, у Италију. Један сасвим другачији живот, кад сте, тако рећи, приморани да загледате, дубље, у себе. Тамо је настало „Стражилово“.

Па је пролазило време.

Онда је дошао живот у иностранству, двадесет и пет година. И ту је, на крају, у Енглеској, дошла лабудова песма, како сам је назвао, „Ламент над Београдом“.

То су епохе живота, епохе поезије. То је нормално, код сваког песника. Моја прва поезија, и „Ламент над Београдом“, то су, тако рећи, две различите поезије.

Везе, међутим, између њих, постоје. Ви имате, у Лирици Ийаке, песама, које такође певају о Београду. 
Ја сам, да Вам то кажем, дошао у Београд, први пут, 1908. године. Мој ујак је живео овде, и завршио, у лудници, из политичких разлога. Зато што је био напредњак, радикали му нису давали мира, прогањали су га. Он је, тако, једног дана ушао у канцеларију, своју, сео на орман, и почео да пева. Био је сишао с ума, Никола Вујић.

Па сам долазио у Београд, често, и зато што сам имао, ту, једну тетку, која је становала у броју 6, преко пута хотела „Москва“, у Балканској.

У оно време је Београд био пун омладине. Тамо, где је данас споменик Доситејев, ту смо се окупљали. То је био весео град, варош весела, која ме је занела, од првог дана.

Тих година јавио сам се у академију, ликовну, али ме нису примили.

Па сам дошао као фудбалер.

Наша генерација је била генерација љубави према свом народу, и према Београду.

И поезија је почела тако. Међутим, кад ви прођете, у животу, педесет, шездесет година, ваша поезија није више лудило. Она је, увек, једно стваралаштво, које трпи промене, стално, и од њих добија. Ви, дакле, тада, тражите оно, што још хоћете да кажете, осећате да је крај близу, и као да се давите.

Да Вам још напоменем, ту је огромна начитаност из страних поезија. Знате неколико језика, занесе вас да има толико великих књижевности, трагедија великих, и великих песника.

Али, паметно је стати. Јер кад човек дође у моје године, онда је меланхолија толико велика, да би било јако смешно да настави да пише песме. То би било жалосно.

Зато сам ја казао, да после „Ламента...“ нећу писати стихове, и нећу штампати. Ућутати треба.

\section{3. ПРАВИ ПЕСНИК НЕ МОЖЕ УМРЕТИ ПРЕ НЕГО ШТО ИСПУНИ СВОЈЕ ЈА, СВОЈУ СУДБИНУ}

Поезија Ваше іенерачије, а нарочит̄о Ваша йоезија, наишла је

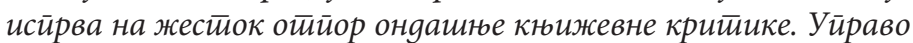
йо неразумеване за нов начин иеевана, за яруїачији, у мноїо

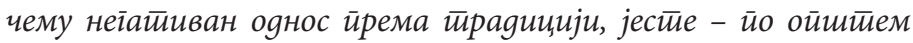


мишльеьу - јеgан ол тиеметних разлоїа, ако не и основни разлої, gа найишеие како „Објашъене Сумайре“, йако и „Коменйаре уз Итаку“.

„Коментари уз Ийаку“су једно, а „Лирика Итаке“, друго. „Коментари“, то је живот, који је довео до поезије, такве.

А то што кажете о критици, то је било тако. То се, и касније, и не само мојим песмама, догађало, Али писац, ако је сачувао своју културу, целу, он онда може да влада својим критичарима. Критичари, знате, не морају увек бити непријатни.

Смешно је, међутим, ако се иза критике скупља нека, зла, намера, или нешто друго, што нема никакве везе са литературом. О мени је, на пример, написано доста, а измишљено много.

Али то је прошло, и сад, кад се осврнем, видим да је то био судбоносни пут, и да прави песник не може умрети пре него што испуни своје ЈА, своју судбину. Ја сам испунио своју судбину, и миран сам пред будућим поколењима.

\section{4. ПОЕЗИЈА ЈЕ, ЛИТЕРАТУРА УОПШТЕ, КОД НАС ВОЉЕНА. ТОГА ИМА ЈОШ САМО У РУСИЈИ}

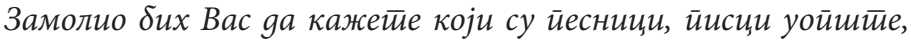
уйииали на Вас као сиивараоца. И занима ме које иеснике саgа читиайе. Читиаиее ли нашу йоезију, савремену, и ову најмлаЂих иесника?

На то је тешко одговорити. Знате, док сам учио гимназију католичких фратара, у Темишвару, дотле су утицали, несумњиво, антички писци.

Кад сам отишао на Бечки универзитет, несумњиво су утицали Немци, Гете и други.

После су утицали и Французи, и Шпанци, које јако волим.

Уживам, одувек, у поезији страних народа, страних песника. Читам Камоенша, Португалца. Гонгора, Шпанац, за мене је велики песник. А има и других: читаво шпанско песништво код нас се слабо познаје, а оно је ванредно. 
Враћам се, стално, и енглеским песницима, мојим. Писао сам, о њима, за Книжевне новине. То су: Џефри Чосер, Волтер Рали, Џон Дан, Шели...

Утицали су, дакле, многи, и не само појединци, него целе књижевности, и културе. Навешћу Вам старе Кинезе, стару јапанску лирику.

Мора да су утицали, ако се утицај узме као нешто паметно. Али ако се мисли да сам имитовао, не. Ви ћете наћи песму, коју је Дучић написао, и која је имитација. Можете наћи Ракићеву песму, која је превод из Шекспира. То се код нас није знало: о лепоти оне ноћи мајске...

Неће, међутим, код мене, нико наћи, да је неки песник на мене тако утицао. То ја нисам трпео. То, знате, зависи од вашег карактера писца.

Што сте ме, пак, питали да ли читам нашу поезију, читам, и то са задовољством. И оне најмлађе. Само је, та поезија, другачија. Моја поезија је поезија срца, поезија осећања, а њихова је поезија размишљања.

А то, да имамо на стотине поета, то је једна појава, која је наша. Јер поезија је, литература уопште, код нас вољена. Тога има још само у Русији. Нисам то нашао ни у Француској, ни у Енглеској. Ви, рецимо, у Енглеској имате великих песника, и међу млађима, а штампани су у врло малом тиражу. Педесет четири милиона Енглеза, који, уз то, имају велику поезију, у прошлости, а човеку, кога су сматрали за великог поета, штампају две хиљаде примерака.

\section{5. СТВАРАҢА ИМА ЈЕДИНО ТАМО, ГДЕ ЈЕ ОНО НАГОН ПОДСВЕСТАН}

Осим йоезије, Ви сиие врло рано ӣочели gа објављујетее йрозу. Имаиее ирича, романа, драма. Извесно време бавили сиее се ликовном крииииком. Шииамйали сйе не јеgан есеј о книжевностии. Ваши йуйойиси сйаgају међу врхунска ела йуйо-

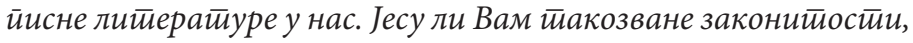
које йодразумева сваки жанр за сеґе, заgавале невоље? 
Прави уметник је рођени балет-играч, и он игра разне врсте балета. Није тачно да су велики писци само они, који умеју да пишу прозу, а не пишу поезију. Или пишу само поезију, а не пишу прозу, не знају да напишу драму, или нешто друго. Сасвим је погрешно мислити, да су једино то прави писци. Стваралац може бити велики и поред тога што мења своје тенденције.

То је као у музици. Ево Казалс, на пример. Он је изабрао чело, али је свирао, ванредно, и виолину, и направио је још, ако хоћете, архитектонску музику, која је концертна.

Тако сам и ја стварао, у књижевности, што сам желео. Писао сам поезију, писао сам и роман, и драму. Ја сматрам да је сваки књижевник, који ради неколико врста књижевнога посла, ситан, ако не уме да буде и поет, и прозаист. Уколико има поезије у прози, то не значи да он не уме да пише песме. Или, ако у песмама има прозе, то не значи да он мора да буде баш песник.

Ви морате да стварате са жељом да то буде оно, што је нагон подсвестан.

Данас се, додуше, о подсвести, више и не говори. То је било кратко време, кад се о томе мислило. Међутим, подсвест у поезији, прози, драми, у свему она има своју улогу. Па и кад се говори о поезији у једном времену.

Узмите, рецимо, Дневник о Чарнојевићу. Та поезија, коју у овој прози налазите, то је занос тог јунака, он живи са њом, и она са њим. Онако, како се његов живот мења, тако се и он мења.

То су, знате, узајамни односи. Без те поезије, не би ни он постојао, такав. Она је његово доживљавање, његов пут у живот. Сећате се, вероватно, вибрирања његових осећања у топовској паљби, или у љубави са оном Пољкињом.

То су, је ли, различите ствари, које повлаче за собом различит језик, различиту реченицу.

\section{6. НЕМОЈТЕ ДА ВЕРУЈЕТЕ ОНИМ ПИСЦИМА, КОЈИ НЕ УМЕЈУ ДА ПИШУ. ТЕШКО ОНОМ КО ЈЕ ЈЕДНОСТАВАН, ОН ЈЕ ДОСАДАН ПИСАЦ}

Ваше стиваралашӣво дало је јеgну сасвим нову, сасвим особену сииилску йехнику, која је gо Ваше йојаве нейознайа у нашој, и не само у нашој кюижевностии. Мислим, у ирвом реgу, на реченички 
склой, на она Ваша у најману руку чудновайа, чудесно изра-

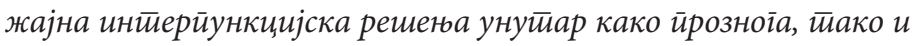
иесничкоі исказа. Критиика у йослеgне време са свом озбильо-

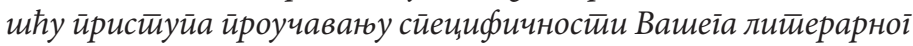
израза, особеностии језика какав стие увели у книжевности. Како Ви објашњавайе йакво своје книжевно иичсмо?

Мој језик је, најпре, чист и јасан, и он се труди да сваку ствар, на њој одговарајући начин, представи. Друкчије говори једна мати, која плаче над умрлим сином, друкчије сељак који се распилавио па је сео да се напије. Моја реченица иде за суштином ситуације, коју прича, за суштином душевног стања, које хоће, читаоцу, да каже, и она то и чини.

А што се тиче многих запета, због којих се шале увек чак се и Иво Андрић шалио, једанпут, на мој рачун, у питању тих запета - то је жеља да ви овладате својим језиком, и да читалац чита реченицу онако, како ја желим да је чита, не како би он хтео.

Вук Караџић, на пример, није имао потребе за запетама, јер је он писао ствари народне, народни језик, тако да је то ишло до тачке.

Данас, међутим, у овом времену, кад ви говорите ствари хипермодерне, ви морате и реченицу тако да правите, и да натерате читаоца да види, и да чита, онако како ви желите. Па да ли је задовољан, или не, то је друго питање.

Према томе, уметнички рад у прози, и у поезији, значи и уметничку вредност. Ви морате то да осећате, и да живите са тим. Немојте да верујете оним писцима, који не умеју да пишу. Није то једноставна ствар, умети написати оно, што се хоће. Тешко оном ко је једноставан, он је досадан писац.

\section{7. СВАКИ ПИСАЦ УНОСИ У КЊИГЕ НЕШТО, ШТО ЈЕСТЕ. АЛИ ТО НЕ ЗНАЧИ ДА УНОСИ ОНАКО, КАКО ЈЕ БИЛО}

Jом у време каg стие објавили Дневник о Чарнојевићу, кри-

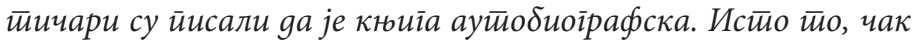
gрастиччније, йоновило се у вези с книїом Код Хиперборејаца. Није, у тиом смислу, йошйеђен ни Роман о Лондону. Ви, 


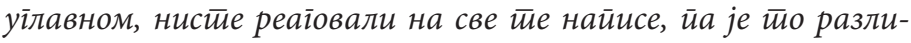
читио ииумачено. Какав је Ваш овнос йрема ирроблему ауйобио-

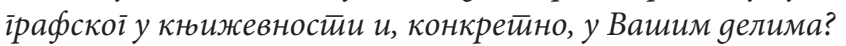

Сви писци пишу биографски. Нема великих, а ни обичних писаца, који не пишу и свој живот. Ако је, од двојице браће, један писац, а други није, то не значи да писац неће унети у књигу оно, што је његов брат доживео.

Оно што сам ја доживео, у Првом светском рату, то је у Дневнику о Чарнојевићу.

Али, тај главни јунак, то нисам само ја.

То је више људи.

Испричаћу шта ми се десило у вези са том књигом. Кад сам се оженио, знате, један познати милионар београдски дојурио је мојој ташти, и казао: „Слушајте, па он је ожењен. Видео сам и књигу, где је то написао!“Ето какви смо ми људи. А та жена, из Дневника..., то је једна жена коју сам само познавао.

Сваки писац уноси у књиге нешто, што јесте. Али, то не значи да уноси онако, како је било.

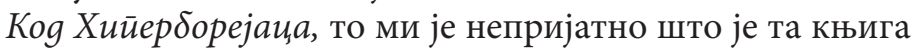
тако мало запажена.

Тамо ја признајем, да пишем ја. Ја сам био на Шпицбергену, био сам на тим путовањима, био сам у Риму, са службом.

Али то не значи, да је моја љубазница долазила тако, а моја жена овако, или да сам био заљубљен у ову или ону. То је ствар коју чак није лепо ни питати једног писца. Ружно је за то се интересовати.

Има много биографског, јер сам то преживео. Јер, на пример, догађај који сам видео, место где је потонула, у мору, сестра моје жене, на истом броду са Дисом, а моја жена се загледала у море и плаче, то је, разуме се, аутобиографски.

Или човек, који је, у Роману о Лонgону, књаз Рјепнин. Он је постојао. Само, он је Пољак, а не Рус, пољски гроф један. Врло много ствари, ту, у књизи, збиља су из његовог живота, а не из мога.

То су и моји пријатељи, многи. Чак су се неки и препознали. Чак су се, неки, и љутили, због тога. 


\section{8. КАД ОСТАРИТЕ, ОНДА, ОБИЧНО, КРИТИЧАРИ ПРЕСТАНУ ДА ВАС НАПАДАЈУ, НЕ СМЕШТАЈУ ВАМ НЕИСТИНЕ, НЕ ПРАВЕ ВИЦЕВЕ}

У релайивно крайком временскоме размаку йојавиле су се йри значајне књиіе, йакорећи моноірафије, йосвећене Вашим gетима. То су оиссене и, за ийа им је о gат̄о ӣризнане, на висо-

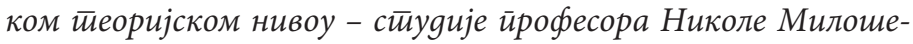
вића и Алексанgра Петирова. Трећа книїа је зборник Инстии-

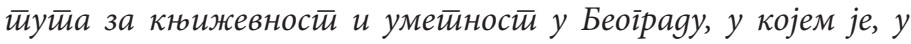
раяовима различитичх аутиора, обухваћено скоро све шито стие gосаg објавили. Како сйе Ви ӣримили ове книїе?

Кад остарите, онда, обично, критичари престану да вас нападају, не смештају вам неистине, не праве вицеве.

Никола Милошевић, ја сам то њему из Лондона написао, појавио се као први, наш, критичар-научник. Његов Роман Милоша Црғанскої је све, што је могуће тумачити, повољно, у моју корист, у тим романима.

Петров има једну лудачку вредноћу, која је фантастична. Он је, несумњиво, нашао везу руског футуризма и мене. И није никакво чудо да је успео. Али је, кажем, толико вредан, да је он не само сваки мој стих, него и сваку моју трећу реч, проучавао, тако да сам се ја смејао.

Зборник је, са своје стране, једна ствар, коју бих хтео да кажем у славу жена. Има, у том зборнику, врло добрих есеја. А има, ту, и један напад, на мене, зато што тај човек не зна да сам ја, о политици иностраној, много више знао, него што он мисли. И много више утицаја имао, него што он мисли. Иначе је то човек од врло лепе вредности, као критичар.

Онда, има ту једна жена, Мирјана Миочиновић, која је написала, о мојој Маски, једну ствар, коју нико пре ње није написао. Разумела је, да ту има позоришта, које је футуристичко. Ту је још једна, Хатиџа Крњевић, која је исто тако добро писала.

Оне су послу критичарском пришле са великим знањем, са великом подученошћу. 


\section{9. ВИ ИЛИ НАЛАЗИТЕ СМИСАО У СВОМЕ ЖИВОТУ, ИЛИ ГА НЕ НАЛАЗИТЕ, ПА МАКАР СЕ РАДИЛО О ТОМЕ ДА СТЕ НАЂУБРИВАЛИ ЗЕМЉУ, ИЛИ КЬИЖЕВНОСТ}

Готиово у свим Вашим делима заокуйлени сиие йитиаюем о

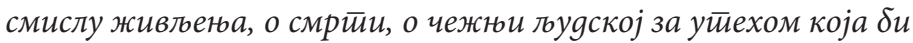

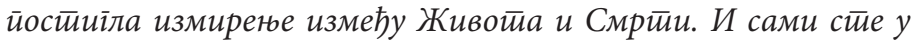

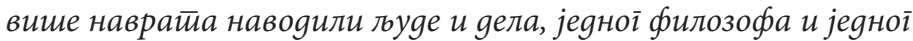
уметиника - чији су животи и дело, за Вас, увек ирреgстиввљали

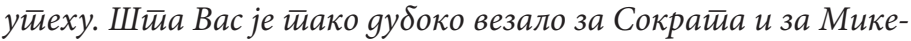
ланђела?

Питање о смислу живота, и о смрти, пре или касније, чека сваког човека. Наравно, и та жеља за утехом, својом, у животу.

Али ви, што је разумљиво, сасвим друкчије видите у добу младости, која је лудило, и која је живот један весео, безбрижан. А кад сте у у осамдесетој, онда неминовно мислите о смрти.

Живот при крају је, живот размишљања. Кад видите сељаке и у најпростијем селу Војводине, у Банату, ви их видите како сваки дан, с вечери, изиђу пред кућу, на клупу. Немојте мислити да они говоре глупости, да говоре неке баналне ствари. Они размишљају о томе, каква је била прошлост, како је завршио неки њихов друг, а онај други остао жив, шта ради онај старац, који је изгубио сина.

Сва драма живота одиграва се, најинтензивније, при крају живота, у размишљању.

И тад ви или налазите смисао у своме животу, или га не налазите, па макар се радило о томе да сте нађубрили земљу, или књижевност.

Тако је и у мојим романима, и песмама, свим.

А Сократ? Сократ умире тако мирно, јер је уверен, да је то смисао живота, да мора имати свога краја.

Или шта је било код Микеланђела, који је остао потпуно сам, целог живота, али није попуштао, ни за тренутак. Четири дана пре смрти он још мења скулптуру, још ради на њој, клеше, и пише сонете, који су потресни, који су поезија ванредна.

Умрети је најтеже за масу, за свет. Цео свет је уплашен, јер је тешко гледати смрти у очи. Утеха је, међутим, ако имате 
да се сетите, нечег лепог, из свог живота, и да знате, да смрт чека, и вас, али да је се не бојите.

Јер то је јасно, да живот пролази, али пролази као што пролеће пролази, као што птице пролазе. Сасвим лепо.

\section{0. ОСАМ ГОДИНА РАДИМ, А ПЕДЕСЕТ ГОДИНА САМ СЕ ИНТЕРЕСОВАО О МИКЕЛАНЪЕЛУ}

Већ gуіо йроучаваиее животи и gело Микеланђелово. Скулй-

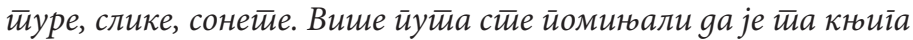
ири крају, gа је завршаваиее. Каяа је можемо очекиваиич?

Осам година радим, а педесет година сам се интересовао о Микеланђелу.

Сад, кад сам, за осам година, видео неколико изложби и филмова, нарочито филмова, нове, американске, о њему, и о његовим сликама, направићу књигу о извесним стварима, за које мислим да нису тачне, да су тенденциозне, и, према томе, рећи ћу мирно то што мислим.

Та књига ће бити готова, ускоро, и брзо може да се штампа, ако само очи буду издржале.

Јер ја пишем руком, сам, па то, после, иде у машину. Дакле, то је, прилично, напорно.

Разіовор водио

Јован Пејчић 